\title{
Self-Control and Self-Regulated Learning on Students
}

\author{
Self-Control dan Self-Regulated Learning pada Siswa
}

\author{
Dita Praweswari ${ }^{1}$, Nur'aeni ${ }^{2}$ \\ ${ }^{1,2}$ Universitas Muhammadiyah Purwokerto, Indonesia
}

\begin{tabular}{l} 
ARTICLE INFO \\
\hline Article history: \\
DOI: \\
10.30595/pssh.v2i.105 \\
Submitted: June 27, 2021 \\
Accepted: Aug 07, 2021 \\
Published: Sept 24, 2021 \\
\hline
\end{tabular}

Keywords:

Self-Control, Self-Regulated Learning, Student

Organization

\begin{abstract}
Students who are active in non-academic activities can get different academic scores from students who do not participate in student organizations. This study examines the relationship between self-control and self-regulated learning of students who are members of the Student Organization of the University of Muhammadiyah Purwokerto-Indonesia. This study uses quantitative methods. The sample of this research is 88 students who follow the Student Organization. Sample selection using probability sampling technique by taking $14 \%$ of the total population. Data were collected using an online questionnaire, and namely, google Forms. The instrument used is a scale of self-control and self-regulated learning. The data analysis technique uses the product-moment method from Karl Pearson. This study indicates a positive and significant relationship between self-control and self-regulated learning in students participating in Student Organizations; the correlation value of $r$ is 0.689 at $p$ $=0.000(\mathrm{p}<0.01)$.
\end{abstract}

This work is licensed under a Creative Commons Attribution 4.0 International License.

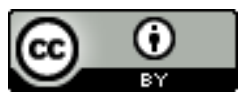

\section{Corresponding Author:}

Dita Praweswari

Universitas Muhammadiyah Purwokerto, Indonesia

Email: dythapraweswari@yahoo.com

\section{INTRODUCTION}

Community life in the present era is indeed more rapidly developing, including science, skills, and technology. Some people demand that the world of education is also more advanced and more effective, to have basic abilities to survive and thrive. Basic skills will affect students' readiness who enter the next level of education, including education in higher education (Lubis, 2016).

Higher education is a level of education after high school which includes undergraduate programs. Government regulations regarding higher education explain that universities aim to prepare students to become people who have academic abilities to develop, apply, and add to the repertoire of science and technology. The academic skills that have been mentioned can be obtained through teaching and learning activities by the standards set in the national higher education standards (Suputra \& Susilawati, 2019). One of the levels of high her education has a considerable difference compared to upper secondary level education. These differences can be seen in learning objectives, educational systems, administrative systems, learning systems, deeper learning materials, learning facilities, and the learning atmosphere in the classroom (Supriyanto, 2017).

Students in the Republic of Indonesia Law prepare students to register and study social realities that several universities standardize. Everyone officially reported to be closely related to the background takes lessons at the university owned by the student (Sarwono in Mufti, 2018).

Students generally apply independent learning and are no longer dependent on lecturers. Even most students live independently and no longer rely on their parents as no one has told them to study to achieve better performance. Students are also asked to use their time effectively to learn regularly according to their schedule to achieve good learning outcomes (Hendrayana \& Thaib, 2014).

Students are expected to have hard skills and soft skills. Hard skills are the mastery of knowledge and skills acquired through education in the classroom or the field. In comparison, soft skills are the learning ability of science directly and based on theory without training (Pradnyani, 2016). Student Activity Unit developed by students. In 
addition, the Student Activity Unit also has the same vision and mission: to act as a container for student activity and creativity in developing special interests, talents, and skills possessed by each individual in it, such as the Student Activity Unit (Apriliani et al., 2020).

Each has activities in their respective fields from the Student Activity Unit and has their differences in movements. Indirectly students are also required to study acting and achieve better academic and non-academic, but in reality, not all students can succeed in achieving good academic results. In general, students' abilities in the educational field are different. Not all students can get good grades, but some get low learning process rates or understand the material. This affects each individual, one of which is the ability to self-regulate in learning or student self-regulated learning, which differs from one student to another (Jagad \& Khoirunnisa, 2018).

Self-regulated learning is one of the skills that need to be possessed by a student so that they can get the maximum achievement or learning value and satisfactory results. Various research results show that self-regulated learning needs to be a skill that a student optimizes because it affects their learning outcomes (Broadbent et al. in Saputra et al., 2019).

Steffens' statement (in Latipah, 2010) states that with Self-Regulated Learning, students become masters in regulating their learning or Self-Regulated Learning and can improve their learning outcomes. Even though a student has a good level of intelligence, personality, and supportive environment, the student will still not achieve optimal learning outcomes without being supported or assisted by Self-Regulated Learning abilities.

The definition of self-regulated learning itself is when students or students activate or develop their thoughts, feelings, and actions to be more active to achieve a specific educational goal (Zimmerman, 2000). Self-regulated learning refers to a person's thoughts, feelings, and actions produced by the individual himself to achieve a specific purpose (Butler et al. in Kramarski \& Michalsky, 2009). Self-regulated learning is the individual's thoughts, feelings, and actions to achieve particular goals (Butler et al. in Kramarski \& Michalsky, 2009). Self-regulated learning can control the learning process, develop their minds to think independently, and encourage students to pay attention to learning methods for themselves (Bonner et al. in Chen, 2002).

The aspects of self-regulated learning consist of three parts. First, metacognition, namely the ability of individuals to plan, organize or regulate, instruct themselves, monitor, and evaluate learning activities. Secondly, intrinsic motivation, namely, arises and grows from within the individual himself without coercion or encouragement from others, but based on their own will. Intrinsic motivation can be created by fostering a feeling of curiosity, a desire to try, and a desire to advance in learning-lastly, behaviors. Dynamic behavior in self-regulation is individual efforts to regulate themselves, choose, and utilize an environment that supports learning activities or forms of behavior or actions (Zimmerman in Alfina, 2014).

Some factors influence self-regulated learning. The individual includes the individual's knowledge, meaning that the more varied expertise a person has, the more it will help individuals manage. The higher the level of metacognitive ability possessed by individuals will support the implementation of self-management. Second, Behavior, namely the behavior itself, refers to the individual's efforts to use their abilities. The greater the individual's step in self-regulating and being able to organize an activity, it will result in an increase in the management of the individual himself. The third environment is the cognitive, social environment that affects the social and experience of human functioning itself. This depends on how the environment supports or does not support it (Zimmerman in Ghufron \& Suminta, 2017).

Students who have high self-control will behave more positively and responsibly as students. Meanwhile, suppose the individual's self-control is low. In that case, the individual will find it difficult to control his emotions and thoughts, causing problems such as difficulty dividing study time, lazy learning, unable to solve problems in education (Marsela \& Supriatna, 2019). When students have good self-control, they can apply disciplined behavior well because students with good discipline tend to be easier to achieve learning success. Therefore, the more disciplined students are, the better their learning outcomes will be. In addition to the influence of disciplinary behavior, students who receive attention and support from the surrounding environment will increase their independence and have more satisfying results than students who do not get attention and support from the environment (Kholifah \& Rusmawati, 2018).

Therefore, students must have better self-control to choose positive behavior in responding to the problems they will face. Self-control has various functions and benefits for students' lives. When students can control themselves, it will affect their ability to control themselves in behavior, regulate emotions, make decisions, and interact well (Sari et al., 2017). The purpose of this study was to determine the relationship between self-control and self-regulated learning in students participating in the Student Activity Unit at Universitas Muhammadiyah Purwokerto-Indonesia.

\section{THEORITICAL FRAMEWORK}

There are two variables used in this study; those are self-regulated learning and self-control

\section{Self-Regulated Learning}

The basic theory of Self-Regulated proposed by Bandura results from a causal structure interdependent on human behavior and the environment (environment). This aspect is a combination of determinants in Self-Regulated Learning (Bandura, 1995). Self-regulated learning is the process of developing thoughts, feelings, and behaviors more actively in planning, mentoring (monitoring), and evaluation to achieve a specific educational goal (Zimmerman, 2000). The independent learning process depends on the individual's learning motivation; individuals develop and measure cognition, metacognition, behavior and monitor progress in learning (Baumert in Dinata et al., 2016). Self-regulated 
learning can monitor oneself in thinking, emotions, and behavior to achieve specific goals in the learning process (Santrock in Jagad \& Khoirunnisa, 2018). Self-Regulated learning is an individual who is responsible for his personality, including self-control and efforts to improve independent learning (Azmi, 2016). Self-regulated learning is individuals controlling their behavior, motivation, influence, and cognition, trying to achieve a goal (Pintrich in Yukselturk \& Bulut, 2009).

Based on this description, it can be concluded that self-regulated learning is independent learning to activate or train students' abilities to improve or monitor themselves in thinking, emotions, and behavior to achieve satisfactory learning outcomes. Aspects of self-regulated learning consist of three parts according to (Zimmerman in Alfina, 2014): One, metacognition is a person's ability to organize, plan, monitor, organize or instruct oneself, evaluate in learning activities. Two, intrinsic motivation is the motivation that arises and grows from within the individual himself without any coercion or encouragement from others but based on his own will. Intrinsic motivation is created by fostering curiosity to try to advance in learning. Three, behavior, namely dynamic behavior in self-regulation, is an individual's effort to regulate himself, choose and utilize an environment that supports learning activities or forms of behavior or activities carried out. a) Metacognition is a person's ability to organize, plan, monitor, organize or instruct oneself, evaluate learning activities. b) Intrinsic motivation is the motivation that arises and grows from within the individual himself without any coercion or encouragement from others but based on his own will. Intrinsic motivation is created by fostering curiosity to try to advance in learning. c) Behavior, namely dynamic behavior in self-regulation, is an individual's effort to regulate himself, choose and utilize an environment that supports learning activities or forms of behavior or activities carried out.

Some factors influence self-regulated learning (Zimmerman in Ghufron \& Suminta, 2017). First, an individual is the level of metacognitive ability possessed to assist the implementation of self-management. Second, behavior refers to the individual's efforts to use their abilities. Third, the environment is the cognitive, social environment that affects the social and experience of human functioning itself.

One of the factors that significantly influence self-regulated learning is behavior. The greater the effort exerted by individuals in self-regulating and organizing an activity will increase the management of the individual itself. These efforts are in self-regulation, choosing, and utilizing an environment that supports learning activities, behavior, or actions carried out to improve learning achievement.

\section{Self-Control}

The basis of Skinner's approach is that behavior is caused by being influenced by external variables. There is no form of internal activity that affects behavior in humans, but the external stimulus and reinforcement strengthen. Humans can change it through the process of self-control (Skinner in Alwisol, 2018). Self-control is an individual who can behave in a more directed manner and channel his feelings or thoughts in himself correctly (Hurlock in Pujawati, 2016). Self-control is changing the response consciously and intentionally so that the individual can withstand or eliminate adverse reactions and turn these responses into answers better (Baumeister in Khoir, 2019). Self-control determines one's behavior or controls oneself based on specific standards such as morality, values, and social rules to lead to positive behavior (Tangney, etc. in Marsela \& Supriatna, 2019). Self-control is the ability of the body and mind to do what should be done to make the right decisions (Borba, 2008). Self-control is an individual's decision through cognitive considerations to unify behaviors that have been arranged to improve specific outcomes and goals so that they can control what they want (Lazarus in Thalib, 2010). Self-control is control over one's own will to do something that one wants to do without being hindered by anyone, either by obstacles or forces that come from within the individual (Gleitman in Thalib, 2017). Based on this description, it can be concluded that self-control is an act of an individual's ability to control, regulate, control, guide, direct over themselves such as thoughts, emotions, feelings, behavior.

Three aspects affect self-control. Those are behavioral control (behavioral control), cognitive control (cognitive control), and decision control (decisional control) (Averill in Fata, 2020). As explained as follows: 1) Behavioral control is the ability to change an unpleasant situation. The ability to control behavior is divided into two components. It is first regulating the implementation (regulated administration). It is decisions about who will play a role in controlling the condition or situation, whether an individual or something outside the individual. If the individual controls it, then the ability to control oneself is good, and vice versa. Second, the ability to modify the stimulus (stimulus modifiability). The individual can determine undesirable conditions and situations. 2) Cognitive control can process unwanted information by assessing, interpreting, or relating an event within a cognitive framework as a psychological adaptation or reducing stress. 3) Control in making decisions (decisional control), that is, the individual's ability to take any action that he chooses based on something that has been approved.

The factors that influence self-control are divided into two aspects, namely, oneself (internal) and outside oneself (external) (Gunawan, 2017). As explained as follows: the inner self is where age and mindset affect one's self-control. The older a person gets and has a good perspective, and the more individuals can control themselves. Then, outside oneself (external), people are influenced by people around such as the environment, friends, family, primarily parents determine how one can control oneself.

\section{RESEARCH METHODOLOGY}

This study uses quantitative methods with data analysis techniques to test hypotheses, using product-moment correlation analysis techniques from Karl Pearson. The population in this study were students who participated in the 
Student Activity Unit at Universitas Muhammadiyah Purwokerto-Indonesia, amounting to 591 students. The sample in this study used a probability sampling technique, using the type of simple random sampling. Then the sample is taken $14 \%$ of the total population. So that all samples used in this study were 88 students who are members of student organizations. They are collecting data with an online system using Google Forms because, during the COVID-19 pandemic, it limited researchers to meet face-to-face. The research instruments or measuring instruments use a selfcontrol scale (Zimmerman, 2000) and a self-regulated learning scale (Averill in Fata, 2020). Aspects of self-regulated learning consist of three parts, namely metacognition, intrinsic motivation, and behavior. At the same time, the selfcontrol aspect consists of three parts, namely behavioral control, cognitive control, and decisional control. These scales are developed from the elements, and after did the content validity test from the subject matter expert, there are 26 items of the self-control scale and 30 items of the self-regulated learning scale. The self-control scale shows a reliability coefficient of 0.819. Based on these results, it can be said that the self-control scale is reliable. Meanwhile, the selfregulated learning scale shows a reliability coefficient of 0.803 . Based on these results, it can be said that the selfregulated learning scale is reliable.

\section{RESULTS AND DISCUSSION}

From 88 data collected, the description detail of the data can be seen in Tables 1 and

Table 1. Data Description of Self-Control

\begin{tabular}{lccc}
\hline \multicolumn{1}{c}{ Categories } & Score range & Frequency & $\begin{array}{c}\text { Percentage } \\
(\%)\end{array}$ \\
\hline Very high & $\mathrm{X}>110.61$ & 4 & 4,5 \\
High & $99.26<=\mathrm{X}<=110.61$ & 21 & 23,9 \\
Middle & $87.90<=\mathrm{X}<99.26$ & 37 & 42,0 \\
Low & $76.55<=\mathrm{X}<87.90$ & 23 & 26,1 \\
Very low & $\mathrm{X}<76.55$ & 3 & 3,4 \\
\hline Total & & 88 & 100 \\
\hline
\end{tabular}

Table 4 shows that the categories for each subject with very high self-control are four people or $4.5 \%$, high is 21 people or $23.9 \%$, moderate is 37 people or $42 \%$, low is 23 people or $26.1 \%$, and shallow three people or $3.4 \%$.

Table 2. Description of Data Self Regulated Learning

\begin{tabular}{lccc}
\hline \multicolumn{1}{c}{ Categories } & Score range & Frequency & $\begin{array}{c}\text { Percentage } \\
(\%)\end{array}$ \\
\hline Very high & $\mathrm{X}>129.61$ & 2 & 2,3 \\
High & $115.56<=\mathrm{X}<=129.61$ & 24 & 27,3 \\
Middle & $101.51<=\mathrm{X}<115.56$ & 37 & 42,0 \\
Low & $87.46<=\mathrm{X}<101.51$ & 21 & 23,9 \\
Very low & $\mathrm{X}<87.46$ & 4 & 4,5 \\
\hline Total & & 88 & 100 \\
\hline
\end{tabular}

Table 5 shows that the category of respondents in self-regulated learning is very high as many as two people or $2.3 \%$, high category as many as 24 people or $27.3 \%$, medium category as many as 37 people or $42 \%$, low category as many as 21 people or $23.9 \%$, and deficient category as many as four people or $4.5 \%$. The researcher then tested the hypothesis to determine whether there was a relationship between self-control and self-regulated learning in students who participated in the Student Activity Unit at Universitas Muhammadiyah Purwokerto, Indonesia. The results of hypothesis testing can be seen in Table 3 .

Table 3. Hypothesis Test Results

\begin{tabular}{|c|c|c|}
\hline Variable & Correlation Analysis Result (r) & Significance \\
\hline $\begin{array}{c}\text { Self-Control } \\
\text { Self-Regulated Learning }\end{array}$ & 0,689 & 0,000 \\
\hline
\end{tabular}


The results obtained from hypothesis testing using product moment analysis techniques show a positive and significant relationship between self-control and self-regulated learning in students participating in the Student Activity Unit. The correlation value $(r)=0.689$ with $\mathrm{p}=0.000(\mathrm{p}<0.01)$ is in the category of strong and significant correlation (Sugiyono, 2015).

The results of this study are reinforced by research by Mulyana et al. (2015) on self-regulated learning with other factors with positive results. This means that students in dealing with education and other activities are continuous. It can be said that students who have other activities can do self-regulated learning and can control themselves from many activities.

Based on this study's results, from a sample of 88 students who participate in the Student Activity Unit, $2.3 \%$ or two students can have very high self-regulated learning, and the rest have other namely high categories. Get a percentage of $27.3 \%$ or 24 students; the medium type gets $42 \%$ or 37 students. The standard type receives a rate of 23.9 or 21 , and the deficient category gets a percentage of 4.5 or 4 students.

Self-regulated learning is an essential part of independent learning because independent learning refers to the results of systematic thinking and personal behavior to achieve learning that is oriented towards learning objectives. Students actively participate in their learning goals and control their achievement. Self-regulated learning is essential for students because students are required to learn independently; Therefore, students need to organize the learning process alone. Saraswati's research (2017) finds that high self-regulated learning students will produce exemplary achievements, but when self-regulated learning is low, they will make low achievement.

The results of Mulyani's research (2013) show that in addition to self-control and effort in managing their learning, students also regulate the physical environment or themselves to be conducive and have high enthusiasm to support learning activities. The practical contribution of self-control with self-regulated learning in students who participate in the Student Activity Unit at Universitas Muhammadiyah Purwokerto-Indonesia is 0.468. It can be interpreted that self-control contributes $46.8 \%$ to self-regulated learning in students who participate in the Student Activity Unit. At the same time, 53.8\% is influenced by other factors not examined in this study. Other external factors or internal factors support the research results; namely, individuals can adapt to the broader social and situational environment to regulate themselves in self-regulated learning. So that individuals who study independently will get good results in learning objectives. Still, students must be aware and responsible for themselves and know effective learning strategies or have good self-regulated learning strategies (Fasikhah \& Fatimah, 2013).

\section{CONCLUSION}

Based on the results of the analysis and discussion of the relationship between self-control and self-regulated learning in students participating in the Student Activity Unit at Universitas Muhammadiyah Purwokerto-Indonesia, it can be concluded that all hypotheses in this study are accepted. This study concludes that there is a significant and positive relationship between self-control and self-regulated learning. That means, if someone has high self-control, it will be high self-regulated learning also in them. So, students who can manage behavior in their activities also have increased abilities to monitor themselves in thinking, emotions, and behavior to achieve their learning goals.

\section{REFERENCES}

Alfina, I. (2014). Hubungan Self-Regulated Learning dengan Prokrastinasi Akademik pada Siswa Akselerasi. EJournal Psikologi, 2(2), 227-237.

Alwisol. (2018). Psikologi Kepribadian : Edisi Revisi. Universitas Muhammadiyah Malang.

Apriliani, S. L., Esabella, S., Julkarnain, M., Informatika, P. S., Teknik, F., \& Sumbawa, U. T. (2020). Rancang Bangun Aplikasi Monitoring Unit Kegiatan Mahasiswa (Ukm) Universitas Teknologi Sumbawa Berbasis Web. Jurnal Teknik Sains, 1(2), 18-22.

Azmi, S. (2016). Self Regulated Learning Salah Satu Modal Kesuksesan Belajar dan Mengajar. Jurnal Seminar Asean, Psychology Dan Humanty., 1(7), 400-406.

Bandura, A. (1995). Self Efficacy In Changing Societies. In 2017 12th International Conference on Ecological Vehicles and Renewable Energies, EVER 2017. Cambridge University Press, New York. https://doi.org/10.1109/EVER.2017.7935960

Borba, M. (2008). Membangun Kecerdasan Moral. Gramedia Pustaka Utama.

Fasikhah, S. S., \& Fatimah, S. (2013). Self-Regulated Learning (SRL) dalam Meningkatkan Prestasi Akademik pada Mahasiswa. Jurnal Ilmiah Psikologi Terapan, 01(01), 145-155.

Fata, R. (2020). Pengaruh Dukungan Organisasi dan Kontrol Diri Terhadap Disiplin. Jurnal Psikologi, 16(2), 28-36.

Ghufron, M. N., \& Suminta, R. R. (2017). Hubungan antara kepercayaan epistemologis dengan belajar berbasis regulasi diri. Jurnal Psikologi Insight, 1(1), 40-54.

Gunawan, L. N. (2017). Hubungan Antara Kontrol Diri dan Penyesuaian Diri dengan Kedisiplinan Siswa MTs Sulaiman Yasin Samarinda. Jurnal Psikoborneo, 5(1), 104-117.

Hendrayana, A. S., \& Thaib, D. (2014). Motivasi Belajar, Kemandirian Belajar dan Prestasi Belajar Mahasiswa Beasiswa Bidikmisi di UPBJJ UT Bandung. Jurnal Pendidikan Terbuka Dan Jarak Jauh, 15(2), 81-87.

Jagad, H. K. M., \& Khoirunnisa, R. N. (2018). Hubungan Antara Efikasi Diri Dengan Self Regulated Learning Pada Siswa Smpn X. Character: Jurnal Penelitian Psikologi., 5(3), 1-6.

Khoir, A. M. (2019). Kontrol diri dengan tingkat agresivitas remaja yang memiliki orangtua TNI atau POLRI.

Proceedings homepage: https://conferenceproceedings.ump.ac.id/index.php/pssh/issue/view/7 
Cognicia, 7(2), 202-213.

Kholifah, N., \& Rusmawati, D. (2018). Hubungan Antara Keberfungsian Keluarga Dengan Kontrol Diri Remaja Pada Siswa Sman 2 Semarang. Empati, 7(2), 149-159.

Kramarski, B., \& Michalsky, T. (2009). Investigating Preservice Teachers' Professional Growth in Self-Regulated Learning Environments. Journal of Educational Psychology, 101(1), 161-175. https://doi.org/10.1037/a0013101

Lubis, R. H. (2016). Hubungan dukungan sosial dan kecerdasan emosional dengan self regulated learning. Jurnal Analitika, 8(1), 35-55.

Marsela, R. D., \& Supriatna, M. (2019). Kontrol Diri : Definisi dan Faktor. Journal of Innovative Counseling, 3(2), 6569.

Mufti, D. F. (2018). Internalisasi Nilai Nasionalisme Mahasiswa Melalui Organisasi Ekstra Kampus (Deskriptif pada Pergerakan Mahasiswa Islam Indonesian Cabang Tulungagung). Jurnal Rontal Keilmuan Pancasila, 4(2), 57-64.

Mulyana, E., Mujidin, M., \& Bashori, K. (2015). Peran Motivasi Belajar, Self-Efficacy, dan Dukungan Sosial Keluarga Terhadap Self-Regulated Learning pada Siswa. Psikopedagogia Jurnal Bimbingan Dan Konseling, 4(2), 165. https://doi.org/10.12928/psikopedagogia.v4i2.4480

Pujawati, Z. (2016). Hubungan Kontrol Diri dan Dukungan Orang Tua dan Perilaku Disiplin pada Santri di Pondok Pesantren Darussa'adah di Samarinda.eJournal Psikologi, 4(2), 227-236.

Saputra, W. N. E., Handaka, I. B., \& Sari, D. K. (2019). Self-Regulated Learning Siswa SMK Muhammadiyah di Kota Yogyakarta: Kedua Orang Tua Berpengaruhkan? Jurnal Pendidikan (Teori Dan Praktik), 4(1), 7. https://doi.org/10.26740/jp.v4n1.p7-11

Sugiyono. (2015). Metode Penelitian Pendidikan (Pendekatan kuantitatif, kualitatif, dan R\&D). In Alfabeta (Vol. 47, Issue 6). https://doi.org/10.1103/PhysRev.47.506

Supriyanto. (2017). Hubungan Antara Self Regulated Learning Dan Prestasi Akademik Pada Mahasiswa Semester Pertama Prodi Psikologi Universitas Pembangunan Jaya. Widyakala: Journal Of Pembangunan Jaya University, 2(1), 49-61.

Suputra, I. G. D., \& Susilawati, L. K. P. A. (2019). Peran efikasi diri dan kecemasan akademis terhadap self-regulated learning pada mahasiswa Program Studi Sarjana Psikologi Fakultas Kedokteran Universitas Udayana. Jurnal Psikologi Udayana, 6(3), 1293-1302.

Thalib, S. B. (2010). Psikologi Pendidikan Berbasis Analisis Empiris Aplikatif (Pertama). Kencana Prenada Media Group.

Thalib, S. B. (2017). Psikologi pendidikan berbasis analisis empiris aplikatif (Pertama). Kencana Prenada Media Group.

Yukselturk, E., \& Bulut, S. (2009). Gender differences in self-regulated online learning environment. Educational Technology and Society, 12(3), 12-22.

Zimmerman, B. J. (2000). Self-Efficacy: An Essential Motive to Learn. Contemporary Educational Psychology, 25(1), 82-91. https://doi.org/10.1006/ceps.1999.1016 